\title{
The Analysis of Content of Heavy Metals Cadmium (cd) in the Flow of the River Barumun Labuhanbatu Selatan
}

\author{
Sri Kedaton', Arman Harahap ${ }^{2}$ \\ ${ }^{1,2}$ Faculty of Teacher Training and Education, Universitas Labuhanbatu, Indonesia \\ armanhrp82@yahoo.cco.id
}

\begin{abstract}
The number of community activities in the area of River Barumun Labuhanbatu South will produce heavy metals in the waters and will accumulate to the bottom of the waters in the sediment. This study discusses the content of heavy metal Cd in sungai Barumun Labuhanbatu Selatan. The research was conducted in December 2020 until January 2021 in the region of the waters of the River Barumun Labuhanbatu Selatan. The process of sampling using purposive sampling method. Data analysis was done descriptively by looking at the results of the measurements of some parameters of the waters and the test results of water samples in the laboratory by comparing the quality standard according to the Decision of the Minister of Environment No. 51 Year 2004. As for the test sediment samples in the laboratory compared with the raw quality of the concentration of heavy metals in the sediment IADC/CEDA 1997. The results of the heavy metal concentration of $C d$ in the surface water ranged 0,003-0,068 $\mathrm{mg} / \mathrm{l}$, the concentration of heavy metal cadmium in water depth of 5 meters has a range of 0.007-to 0.058 $m g / l$.
\end{abstract}

Keywords

cadmium (Co); water quality, river Barumun Labuhanbatu Selatan

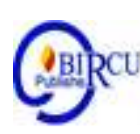

\section{Introduction}

The waters of the river Barumun Labuhanbatu Selatan District City Pinang as one of the shipping routes to get enter the water. Sungai Barumun this not only as a center of the fishing activities in Labuhanbatu, but also into the Sales area fish Sale typical Barumun. Industrial activities on hulu sungai Barumun can give bad impact of metal pollution in the aquatic environment, especially marine life. The flow of the river is widely used by most of the population as a place of catching fish. The number of fishing vessels which are located in the downstream as well as ship-ship industry upstream crossing the River Barumun can result in contamination of the metal of the fuel input boats that pollute the waters to settle in the sediment of the waters.

Heavy metal $\mathrm{Cd}$ into the Aquatic environment of the River Barumun generally derived from the activities of anthropogenic i.e. from industrial activities, fuel, household (domestic) and agriculture. Allegedly the content of heavy metals in the River Barumun has exceeded safe limits.

Naturally, the heavy metal Lead $(\mathrm{Pb})$ can be entered into the waters through the process of efflorescence Lead $(\mathrm{Pb})$ in the air with the help of rain water. While the pollution of $\mathrm{Pb}$ derived from human activity can be sourced from the water discharge (waste) from the industry with regard to $\mathrm{Pb}$, the waste water from the mining beans tin and the result of the disposal of the battery. Waste is flowing through the area or path-the path of the waters further under by the current toward the sea (Mukhtasor, 2007). The source of the metal Lead $(\mathrm{Pb})$ can be derived in addition to the activities of the local and mainland, 
can also be derived from the atmosphere. The source of $\mathrm{Pb}$ metal comes from human activity, the shipbuilding industry and various activities other port is one of the paths that accelerate the occurrence of the increase in the solubility of metals in water bodies. $\mathrm{Pb}$ exposed on the ground and can enter into the waters in the form of ions as pb2+ and $\mathrm{Pb} 4+$. Ion $\mathrm{Pb}$ can be entered into the tissue of living beings forming a 52 a complex compound of an organic protein called metalotionin. The heavy metals are accumulated in the body of the organism if it exceeds the tolerance limit can damage the metabolic system (Palar, 1994).

The content of $\mathrm{Pb}$ in water is low while the content of $\mathrm{Pb}$ in the sediment high this is due to the nature of the heavy metals that cannot be decomposed (non-biodegradable) and accumulative that will continue to grow and eventually settles on the sediment while the crab Crab (Portunus pelagicus) is a sand crab usual hiding in the sand. even on the prowl dipasir like to eat the flesh of shellfish, moss even detrivor. The content of heavy metals in crab Crab (Portunus pelagicus) is caused by nature or the way of life that little movement or a sedentary life and obtain their food by means of the "scavenger, deposit feeders, and filter feeders", so it can accumulate metals sedimentation flock on the base substrate (Mukhtasor, 2007).

Heavy metal is in addition to affecting the quality of water resulting in environmental conditions do not conform any longer to the designation, also will effect on the biological resources of the waters, because of the nature of the heavy metals that accumulated on the body of the biota. According to Darmono (1995) accumulation occurs because of the process of absorption of heavy metals that enter the body through the respiratory tract and the gastrointestinal tract. This process is the longer lead to the increase of heavy metals in the body tissues of aquatic organisms and can cause death of the organism. The purpose of this study is to determine the concentration of heavy metals cadmium $(\mathrm{Cd})$ in the water and in the sediment in the Waters of the River Barumun LabuhanBatu Selatan, find out whether the Waters of the River Barumun is polluted or not based on the quality of the raw as well as see the relationship to the content of heavy metals Cadmium (Cd) in water.

\section{Research Methods}

This research has been conducted in December 2020 - January 2021 in the waters of the river Barumun Labuhanbatu Selatan District Kota Pinang.

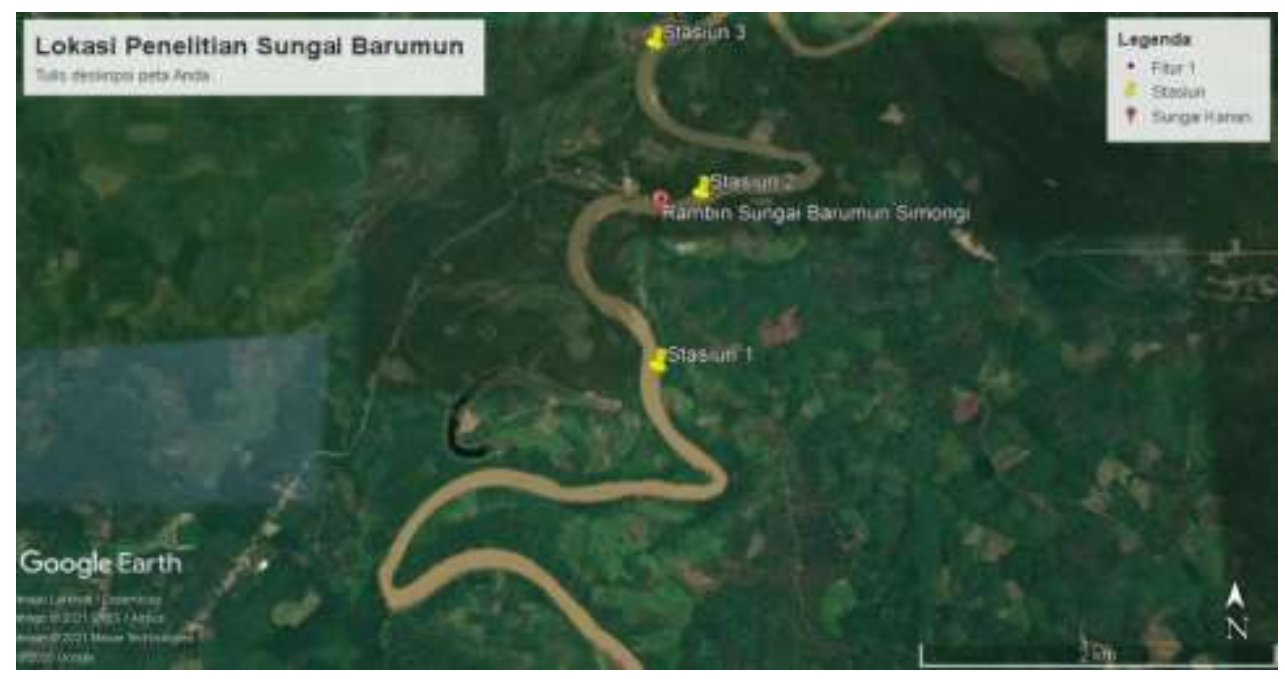

Figure 1. Location research 
The determination of the observation stations is done by using purposive sampling method. Observations and pegukuran carried out at three stations. Data analysis and heavy metal carried out in the Laboratory. The collection of field data is done in the form of data of water samples, sample the sediment as well as some of the parameters waters include : temperature, salinity, $\mathrm{pH}$, turbidity and $\mathrm{DO}$ carried out at all points of observation stations. The results of measurements of the parameters of the waters further tabulated and analyzed to determine the ecological state of waters as a whole. The research Data is obtained through three ways, namely the measurement of the parameters of the waters, water sampling, and measurement of the concentration of heavy metals in water were performed in the laboratory. Water sampling to measure the content of heavy metals is carried out in two depths of the water surface and the water depth of five meters. The procedure for the analysis of the content of heavy metals Cd using Atomic Absorption Spectrophotometry (AAS).

Table1. The location of the sampling station research

\begin{tabular}{|c|c|c|}
\hline $\begin{array}{l}\text { Research } \\
\text { Station }\end{array}$ & $\begin{array}{l}\text { Geographic } \\
\text { location }\end{array}$ & Location remark \\
\hline Station 1 & $\begin{array}{l}\text { GL: } 1^{0} 50^{\prime} 6.17^{\prime \prime} \mathrm{U} \\
\text { GB: } 100^{\circ} 4^{\prime} 26.62^{\prime \prime} \\
\text { T }\end{array}$ & $\begin{array}{l}\text { The study site adjacent to residential areas and areas } \\
\text { tangkahan canoe canoe residents of such settlements }\end{array}$ \\
\hline Station 2 & $\begin{array}{l}\text { GL: } 1^{0} 50^{\prime} 4,34^{\prime \prime} U \\
\text { GB: } 100^{0} 4^{\prime} 24.58^{\prime \prime} \\
\text { T }\end{array}$ & $\begin{array}{c}\text { The location of the research terlrtak on the bridge } \\
\text { close to the urban areas and in the vicinity of the } \\
\text { bridge was filled with fish traders a result of the river } \\
\text { Barumun }\end{array}$ \\
\hline Station 3 & $\begin{array}{c}\text { GL: } 1^{0} 50^{\prime} 37.36^{\prime \prime} \mathrm{U} \\
\text { GB: } 100^{0} 4 \text { ' } 15,43^{\prime \prime} \\
\text { T }\end{array}$ & Far from residential areas \\
\hline
\end{tabular}

The materials used in this study include : plastic Bottles $600 \mathrm{ml}$, cool box, eikmann grab, plastic clip, paper label, Global Positioning System (GPS), thermometer, salinometer, litmus paper, camera, stationary and equipment used in the laboratory, such as : the balance of analytical, measuring cup, pipette measurement, atomic absorption spectrophotometer and other.

\section{Data Analysis}

Data analysis of research conducted with descriptive method with seeing the results of measurements of some parameters of the waters and see the results of the test samples of heavy metals in water by comparing it with quality standards according to the Decision of the Minister of Environment No. 5124 years about the Quality of the Raw Water .

Table 2. The criteria of a water quality standard for marine biota $(\mathrm{mg} / \mathrm{l})$

\begin{tabular}{cl}
\hline Logam Berat & $\begin{array}{l}\text { Kepmen LH } \\
\text { No. 51 Tahun 2004 }\end{array}$ \\
\hline Kadmium $(\mathrm{Cd})$ & 0,001 \\
\hline
\end{tabular}


Data for each parameter waters will be tabulated in the form of tables and data from the results of measurements of heavy metals in the water will be tabulated using Microsoft Office Excel software that will then be described through the histogram formed from the data that have been processed. Correlation analysis of the content of heavy metals in the water are also performed using Microsoft Office Excel software.

\section{Results and Discussion}

Its physico-chemical characteristics of the waters of the river Barumun influenced by various factors. The field measurement results show the value of the temperature of the waters ranged from 22.9 to $38,5 \mathrm{oC}$. For other parameters such as salinity ranges from 812 , $\mathrm{pH}$ with a range of values 7,32-7,72, turbidity ranged from 4,18-15,86 NTU, and DO be in the range of values $4,20-6,80 \mathrm{mg} / \mathrm{l}$. The value of the temperature, salinity, and $\mathrm{pH}$ of the waters of the river Barumun able to tolerated a biota of the river. The value of turbidity in the Waters of the River Barumun only one station that still qualify quality of the raw Kepmen LH No. 51 year 2004 for the life of the biota of the river water. Whereas in other stations already exceeds the quality of the raw quality of the raw Kepmen LH No. 51 year 2004 amounted to $<5$ NTU. So is the case with DO, where DO the waters during the observations it can be concluded that the Waters of the river Barumun are under the raw quality of the Decision of the Minister of Environment No. 51 Year 2004 value above 5 $\mathrm{mgO} 2 / \mathrm{l}$. There is only one station during the observations show the value of the $\mathrm{DO}$ in the top $5 \mathrm{mgO} 2 / \mathrm{l}$.

The results of the analysis of the concentration of heavy metal cadmium in the water the Waters of the River Barumun shows the value of which varies at each time of sampling. Sampling of water is carried out at 2 depths, i.e. on surface water and water at a depth of 4 meters. The results of the analysis of the concentration of cadmium in surface water in the Waters of the River Barumun ranges between 0,003-0,073 mg/l. The concentration of Cadmium highest found in station 2, while the lowest concentration was found in station 3 and 1. The results of the analysis of the concentration of Cadmium in water depth of 5 meters range between of $0.007-0.048 \%$ ownership $\mathrm{mg} / \mathrm{l}$. The value of the highest concentration was found in station 2 , while the lowest concentration was found in station 3.

The concentration of cadmium tends to decrease at the station down. It is appropriate as the results of research Sanusi (2006) which states that the concentration of heavy metals is likely to decline at a location remote from the mainland. At station 2 tend to have a concentration value higher if compared with other stations. This is due on the station is located close to the Urban obtain runoff pollution load is high enough the good that comes from organic waste and waste inorganic. The waters of the river barumun is downstream of river barumun that along the river there are many industries. The industrial waste pollutants that enter into the Waters of the River Barumun.Secara umum konsentrasi ratarata konsentrasi logam berat kadmium di air setiap stasiun menunjukkan nilai yang telah melampaui baku mutu yang dikeluarkan oleh Kementerian Negara Lingkungan Hidup No 51 tahun 2004 sebesar $0,001 \mathrm{mg} / \mathrm{l}$.

The presence of heavy Metals is also not just there to be on the waterfront but also settles in the sediment and biota. According to Rochyatun et al. (2006) heavy metals will also be accumulated in the sediment and biota through the process of gravity. According to Ali et al. (2013) in general, heavy metals naturally fit into the environment in a way that the presence of weathering minerals, erosion, and volcanic activity. A pathway of heavy metals in the waters can be derived from the sources of natural and also of the activities 
carried out by humans. According to the Palar (2012) natural sources of heavy metal $\mathrm{Cu}$ is from pengkisan (erosion) of mineral rock and dust that contain particulate $\mathrm{Cu}$ in the air while the source of human activity is industry, shipbuilding and household.

According to Yanthy et al. (2013) one of the sources of heavy metals $\mathrm{Cu}$, which comes from household activities is a waste of floor cleaning liquid containing $\mathrm{CuO}$. Lead $(\mathrm{Pb})$ entry into the waters naturally through the efflorescence of lead $(\mathrm{Pb})$ in the air with the help of rain water as well as the process korosifikasi of rocks minerals due to wave and wind (Palar, 2012). According to Sudarmaji et al. (2006) sources of Pb, which is derived from the battery industry, cable industry and industry kima and the results of fuel-burning vehicles. Research on the content of heavy metals $\mathrm{Cu}$ and $\mathrm{Pb}$ in the waters of the industrial area of the Bay of Lampung on the water and sediment is necessary to evaluate how big of pollution that occurs in those areas and to know where the source of the increased concentration of heavy metals in sediments are used as indicators by using standard quality guidelines, namely the enrichment factor.

The concentration of heavy metal cadmium in sediment in general, if compared with Dutch Quality Standards for Metals in Sediment (IADC/CEDA, 1997) metal concentration of cadmium in the sediment in the Waters of the River Barumun belonging to the target level because the value of the concentration is smaller than the raw quality of the target level, i.e. $<0.8 \mathrm{mg} / \mathrm{l}$. The value of $2 \mathrm{mg} / \mathrm{l}$ is the limit that can still be tolerated for human health and aquatic ecosystems. Similarly, if compared with the standard of the EPA, with the value of the quality standard of $1 \mathrm{mg} / \mathrm{l}$, then in general, the metal concentrations of cadmium in the sediment are still below the quality standard and is still not polluted.

\section{Conclusion}

The results showed that the concentration of heavy metal cadmium on the water surface in the Waters of the Estuary of the River Banyuasin have a range of 0.002-0,062 $\mathrm{mg} / \mathrm{l}$, the concentration of heavy metal cadmium in water depth of 5 meters have an average range of are $0.008-0,057 \mathrm{mg} / \mathrm{l}$. The concentration of cadmium in the water column did not exceed the quality standards issued by the KepMen LH No. 51 year 2004 to aquatic biota. While the concentration of mercury in some stations also have been under the raw quality by KepMen LH No. 51 year 2004.

\section{References}

Ali, H., Khan, E. \& Sajad, M.A. 2013. Phytoremediation of Heavy Metals Concepts and Applications. J. Chemosphere. 869-881

Darmono. 1995. Logam dalam Sistem Biologi Makhluk Hidup. Jakarta:UI Pres

Darmono. 2001. Lingkungan Hidup dan Pencemaran, Hubungannya dengan Toksikologi Senyawa Logam. Jakarta: UI-Press.

Fardiaz S. 2005. Polusi Air dan Udara.

Yogyakarta: Kanisius.

IADC/CEDA Staff. 1997. Environmental Aspects of Dredging: 2a. Convention, Codes, and Conditions: Marine Disposal. Netherlands: International Association of Dredging Companies.

Menteri Negara Lingkungan Hidup. 2004. Surat Keputusan Menteri Negara Lingkungan Hidup Nomor: 51 Tahun 2004 tentang Baku Mutu Air Laut untuk Biota Laut. Jakarta: Kemen-LH.

Mukhtasor. Pencemaran Pesisir dan Laut. Jakarta: Pradnya Paramita, 2007. 
Palar, H. 2012. Pencemaran dan Toksikologi Logam Berat. Jakarta: Rineka Cipta. 152 hal

Palar, Pencemaran dan Toksikologi Logam Berat. Jakarta: Penerbit Rineka Cipta Jakarta, 1994.

Sudarmaji, Mukono, J. \& Corie, I.P. 2006. Toksikologi Logam Berat B3 dan Dampaknya terhadap Kesehatan. J Kes. Ling. 2(2):129-142

Rochyatun, E., M. T. Kaisupy, A. Rozak. 2006. Distribusi Logam Berat dalam Air dan Sedimen di Perairan Muara Sungai Cisadane. Makara Sains 10(1): 35-40

Sanusi H. 2006. Kimia Laut: Proses Fisik Kimia dan Interaksinya dalam Lingkungan. Bogor: Institut Pertanian Bogor.

Syarifudin A. 2012. Kajian sediment transport sungai banyuasin sebagai alur rencana pelabuhan samudera tanjung api-api. http://blog.binadarma.ac.id/achm ad_syarifudin/Transpor+Sedimen html

Yanthy, K.I., E. Sahara, K.S.P. Dewi. 2013. Spesiasi dan Bioavabilitas Logam Tembaga (Cu) pada Berbagai Ukuran Partikel Sedimen di Kawasan Pantai Sanur. Jurnal Kimia. 7(2):141-152 